S. Afr. J. Agric. Ext.

Vol. 44, No. 2, 2016: $147-157$

Dube, Francis

DOI: http://dx.doi.org/10.17159/2413-3221/2016/v44n2a408

\& Maliwichi.

(Copyright)

\title{
POULTRY-BASED POVERTY ALLEVIATION PROJECTS IN EHLANZENI DISTRICT MUNICIPALITY: DO THEY CONTRIBUTE TO THE SOUTH AFRICAN GOVERNMENT'S 'DEVELOPMENTAL STATE' AMBITION?
}

\author{
Dube, M. H., ${ }^{30}$ Francis, J. ${ }^{31} \&$ Maliwichi, L. L. ${ }^{32}$ \\ Correspondence Author: J. Francis - Email: Joseph.francis@ univen.ac.za
}

\begin{abstract}
The aim of this study was to identify both institutional and production constraints to the success of poultry-based poverty alleviation projects (PAPs) in Bushbuckridge Municipality of the Ehlanzeni District of Mpumalanga Province. A mixed methods research design was used. Purposive sampling was used to select 10 Chairpersons, 20 ordinary members, and five extension officers of PAPs who served as respondents in the study. Face-to-face interviews were conducted using a semi-structured guide to collect qualitative data. The qualitative data was analysed using the Atlas ti 7.0.81 software. The results were used to develop a questionnaire employed to collect quantitative data from 116 respondents. The Statistical Package for Social Sciences (SPSS) version 23.0 was used to analyze the latter data. The major institutional constraints identified, in descending order of severity, were: lack of regulation of prices of poultry feed, lack of government start-up capital/subsidy, inadequate extension shows the poor support the PAPs receive. High price of poultry feeds force PAPs to stock fewer chickens was the major production constraint followed by diseases, in particular New Castle and Bronchitis are killing chickens and water supply is so erratic and unreliable that it affects effective running of poultry-based PAPs. It was concluded that despite the wide range of constraints facing them, PAPs were improving people's livelihoods. The need for revamping the local extension service in order to deal with the numerous challenges that the PAPs faced was highlighted. Central to this reengineering of the extension support system is the need for creating platforms and opportunities for the PAPs to co-learn and learn from each other, both of which are fundamental ingredients of sustainability.
\end{abstract}

Keywords: Constraints; developmental state; extension; poverty

$\begin{array}{ll}\text { ABBREVIATIONS AND ACRONYMS } \\ \text { PAPs } & \text { Poverty Alleviation Projects } \\ \text { NDP } & \text { National Development Plan } \\ \text { RDP } & \text { Reconstruction and Development Programme } \\ \text { GEAR } & \text { Growth, Development and Redistribution } \\ \text { SPSS } & \text { Statistical Package of the Social Sciences }\end{array}$

\section{INTRODUCTION}

As is the case with most countries in Africa, South Africa faces numerous socio-economic challenges. These constitute the agenda for economic transformation, growth and

\footnotetext{
${ }^{30}$ Institute for Rural Development, School of Agriculture, University of Venda, Private Bag X5050,

Thohoyandou, 0950, South Africa. Email: helendube1@ gmail.com

${ }^{31}$ Institute for Rural Development, School of Agriculture, University of Venda, Private Bag X5050,

Thohoyandou, 0950, South Africa. Joseph.francis@univen.ac.za

${ }^{32}$ Department of Consumer Sciences, School of Agriculture, University of Venda, Private Bag X5050,

Thohoyandou, 0950, South Africa. Lucy.malwichi@univen.ac.za
} 

Africa as shouldering the burden of socio-economic development. This echoes the views of Mkandawire (2012), who argues that the South African government adopted the developmental state strategy in order to achieve economic growth. Since 1994, the government has been crafting various legislations, frameworks and strategies geared towards fighting poverty, unemployment and inequality. Thus, it was not surprising that former President Thabo Mbeki described poverty as an 'endemic' and 'widespread' challenge that needed urgent attention (Mbeki, 2006).

Policies and strategies introduced to counter poverty include the Reconstruction and Development Programme of 1994, Growth, Development and Redistribution of 1996, and the National Development Plan Vision 2030 that was launched in 2013. Lessons drawn from rural and agricultural development interventions implemented in other parts of the world such as East Asia, indicate that the developmental state model has the potential to yield remarkable success. For instance, application of pro-poor rural and agricultural policies in East Asia resulted in improved of rural incomes and enhanced levels of wellbeing (Routley 2014). Although, the Southeast Asian policy lessons are not a panacea to the South African challenges (Andani, 2012), they highlighted the potential of poultry in contributing to economic development and improving the livelihoods of the rural poor and marginalized groups in society.

Virtually all the development-oriented policies adopted in South Africa to date recognise agriculture as a key driver of rural economic development and job creation. A major pillar of this drive has been the introduction of poultry-based poverty alleviation projects (PAPs), specifically targeting women, youth and residents of rural communities. The relative affordability of poultry meat makes it an important source of protein for millions of lowincome South Africans. This contributes to what Urban-Eco (2013) terms the 'zero hunger' ambition of the government.

This study was partly carried out taking into account the Gallagher (2002) argument that extension services in developing countries are currently grossly under-funded to undertake the activities required for achieving food security while protecting the productive resource base in order to keep up with population and economic growth. In the absence of credible scientifically generated evidence that supports this view with respect to the state of affairs in PAPs, it will remain impossible to develop policies and legislation promoting them as a vehicle for rural economic development. Yet this is crucial for crafting strategies for making PAPs viable and sustainable despite operating in resource-constrained environments.

\section{DEFINITION OF THE PROBLEM}

The need for viable and sustainable poultry-based PAPs in South Africa's drive towards increasing food and nutrition security, and job creation to meet the needs of a growing population is not questionable. However, the PAPs face a wide range of internal and external constraints which hamper their growth and development (Development Bank of Southern Africa: DBSA, 2009). Most worrying is the fact that poultry-based PAPs often collapse once external funding is exhausted or terminated (Makhalane, 2009; Masipa, 2010; Tshitangoni et al., 2010). Even though many studies have been undertaken to build an understanding of the constraints that poultry-based PAPs face, there is still a dearth of agricultural extension usable evidence. Thus, this subject was explored through an empirical qualitative and 
Objective: The objective of this study was to identify the institutional and production constraints to the successful implementation of poultry-based PAPs in order to make suggestions for improved agricultural extension support.

\section{MATERIALS AND METHODS}

\subsection{Study focus and site}

The study focused on the poultry-based PAPs located in Bushbuckridge local municipality of Ehlanzeni District (Figure 1). Ehlanzeni, Nkangala and Gert Sibande Districts make up Mpumalanga Province, which is located northeast of South Africa. Thaba Chweu, Mbombela, Nkomazi and Bushbuckridge local municipalities constitute Ehlanzeni District. The District's total geographical area is $27.896 \mathrm{~km}^{2}$. The GPS coordinates of Ehlanzeni District are: $28^{\circ} 57^{\prime} 25^{\prime \prime} \mathrm{S} 18^{\circ} 06^{\prime} 18^{\prime} \mathrm{E}$ or $28.957^{\circ} \mathrm{S} 18.105^{\circ} \mathrm{E}$. Bushbuckridge local municipality is the most rural of the four that make up Ehlanzeni District. It has a total population of $541248,99.5 \%$ of them being Black Africans. According to Statistics South Africa (2011), the population of Bushbuckridge local Municipality is respectively about $34 \%$ and $14 \%$ of the District and provincial totals. It is renowned for its agricultural and tourism attractions. To the east of the Municipality is the Kruger National Park, while Mbombela Local Municipality lies to the South and Thaba Chweu local Municipality to the south western side. Its geographical area is more than 1000000 ha, after the recent Municipal Demarcation Board expanded the locality by including part of the Kruger National Park. The Municipality is part of the Kruger to Canyon Biosphere. 


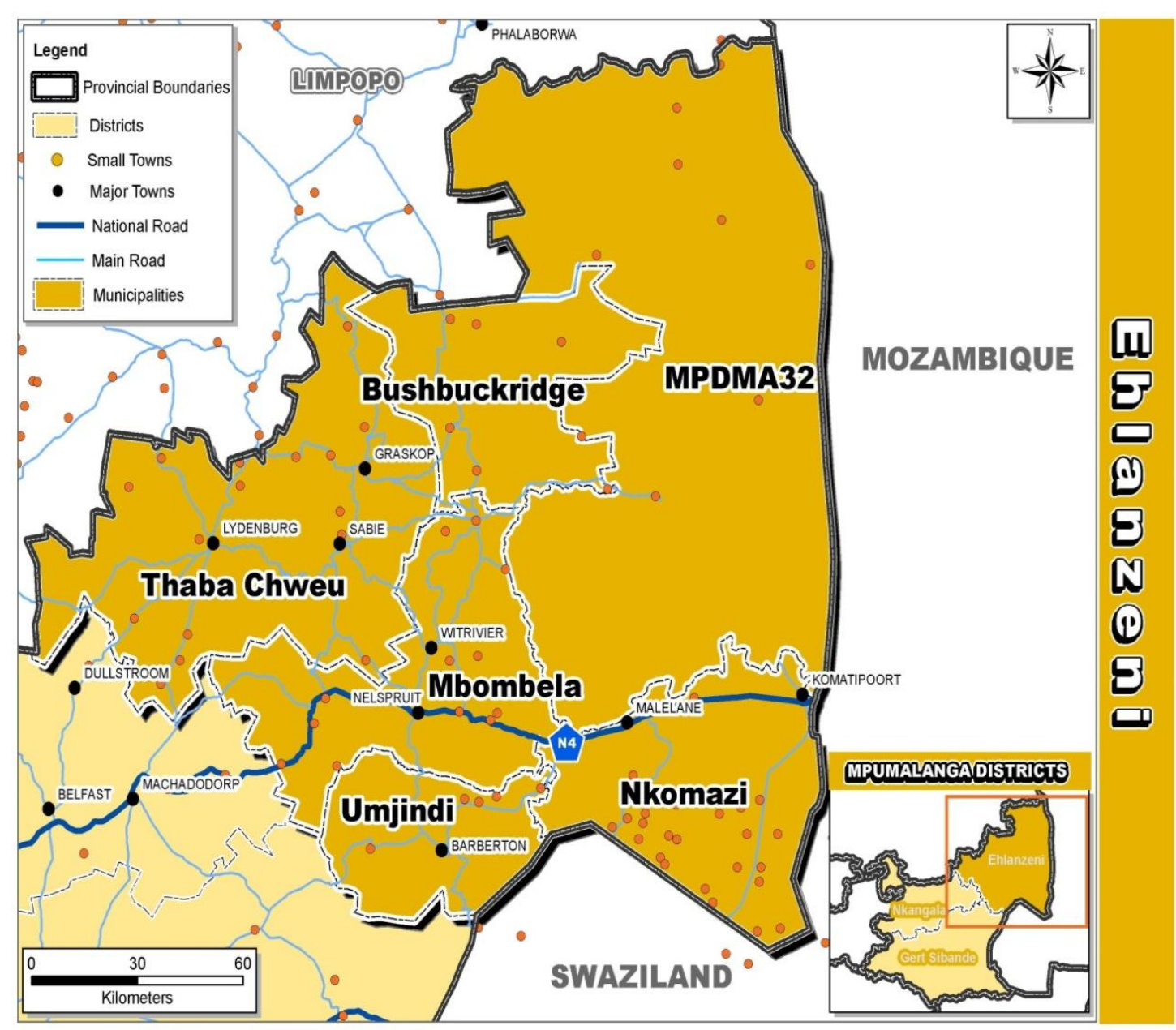

Figure 2: Map of Ehlanzeni showing its constituent local Municipalities and neighbouring countries: Ehlanzeni District Municipality GIS Unit (2010)

\subsection{Sampling procedure and data collection}

A mixed method research design was adopted for this study. In phase 1 of the study, qualitative research was carried out. Purposive sampling was used to select 10 chairpersons and 20 ordinary members of poultry-based PAPs located in the northern and southern regions of Bushbuckridge Municipality. In addition, five agricultural extension officers working for the Mpumalanga Department of Agriculture, Rural Development and Land Administration were selected. Semi-structured interview guides, made up of open-ended questions, were used to collect data during the qualitative study. This made it possible to understand the respondents' constructions of their realities with respect to experiences in running poultrybased PAPs. Probing, as recommended by Merriam (1998), was used to obtain deeper and richer information from the respondents. The results of this study were used to generate a structured questionnaire that was then administered to a purposive sample of chairpersons, secretaries, ordinary members and extension personnel. The first section of the questionnaire was devoted to demographic characteristics of the respondents such as age, gender, marital status and highest level of education. In section two of the questionnaire, data on poultrybased PAPs was included. The last section contained questions on constraints that the PAPs faced. 
S. Afr. J. Agric. Ext.

Vol. 44, No. 2, 2016: $147-157$

DOI: http://dx.doi.org/10.17159/2413-3221/2016/v44n2a408
Dube, Francis

\& Maliwichi.

(Copyright)

\subsection{Data analysis}

Qualitative data was transcribed verbatim and analysed using the Atlas ti7.0.81 software. Data analysis collected using the questionnaire was checked for accuracy and reusability. It was then coded, cleaned and stored as Microsoft Excel spreadsheets. The double entry system was used in order to minimise data entry errors. Discrepancies were corrected through consulting the survey instruments. All the data was non-parametric and was analyzed using the Statistical Package for the Social Sciences (SPSS $®$ ) version 23.0. Frequencies and ranked means were computed. The latter results were used to separately rank the institutional and production constraints.

\section{RESULTS}

\subsection{Demographic characteristics of respondents}

There were more respondents (57\% out of the 116) from the northern region of Bushbuckridge compared to those from the southern part. Females constituted $58 \%$ of the respondents. The modal age group was 51-60 years (39\%), followed by the 36-50 year olds $(37 \%)$. Those less than 35 years old constituted $13 \%$ of the total number of respondents.

Approximately, two-thirds of the respondents were married. The number of members of the households of the respondents varied from 2-13 persons. The proportions of respondents who had attained primary (45\%) and secondary school education but not matriculated (44\%) were almost the same. The rest had never attended school at all.

It was revealed that the respondents had been involved in poultry-based PAPs for periods ranging from one year to about 15 years. Slightly more than half of the respondents $(54 \%)$ had been members of their projects for 5-10 years, compared to 25\% who had been involved for 10-15 years. The rest had been involved in PAPs for at least 15 years (17\%) and 1-5 years $(3 \%)$.

\subsection{Institutional Constraints to Poultry-based Poverty Alleviation Projects}

The ranked institutional constraints to poultry-based PAPs are shown in Table 1. 'Lack of regulation of prices of poultry feeds makes it difficult to run profitable poultry business' was regarded as the major constraint while 'lack of government subsidy' was the second most important challenge. Other constraints were 'inadequate extension shows the poor support the PAPs receive' and 'lack of training, especially in financial management contributes to poor performance of PAPs'. 
Table 1: Ranked means of institutional constraints as perceived by members of poultry-based poverty alleviation projects

\begin{tabular}{|c|c|c|c|}
\hline Constraints & Mean & $\begin{array}{l}\text { Standard } \\
\text { Deviation }\end{array}$ & Rank \\
\hline $\begin{array}{l}\text { a. Lack of regulation of prices of poultry feeds makes it } \\
\text { difficult to run profitable poultry business }\end{array}$ & 1.8 & 0.56 & 1 \\
\hline $\begin{array}{l}\text { b. Lack of government start-up capital/subsidy contributes to } \\
\text { failure of PAPs }\end{array}$ & 1.9 & 1.35 & 2 \\
\hline $\begin{array}{l}\text { c. Inadequate extension shows the poor support the PAPs } \\
\text { receive }\end{array}$ & 3.4 & 1.33 & 3 \\
\hline $\begin{array}{l}\text { d. Lack of training, especially in financial management } \\
\text { contributes to poor performance of PAPs }\end{array}$ & 4.2 & 1.09 & 4 \\
\hline
\end{tabular}

Key:

Rank: position per theme

Mean: the lower the mean score, the more pressing is the issue

\subsection{Production Constraints to Poultry-based Poverty Alleviation Projects}

Table 2 shows the ranked production-related constraints to poultry-based PAPs. 'High price of poultry feeds force PAPs to have fewer chickens than what is required for optimal performance' was ranked the top constraint. The extent to which diseases hampered PAPs was confirmed by 'diseases in particular New Castle Disease and Bronchitis are killing chickens' being regarded as the second major constraint to the performance of PAPs. Other significant constraints were "water supply is so erratic and unreliable that it affects effective running of poultry-based PAPs and 'lack of local hatchery is a barrier for growth and development of poultry-based PAPs. 'Predators such as snakes and dogs contribute to mortalities of chicken' and 'veterinary care (drugs and vaccines) for poultry is very expensive which forces PAP members to resort to using traditional ways that might not be appropriate for high volume commercial production' were the least ranked constraints.

Table 2: Ranked means of production constraints, as perceived by members of poultry-based poverty alleviation projects

\begin{tabular}{|l|l|l|l|}
\hline Constraints & Mean & $\begin{array}{l}\text { Standard } \\
\text { Deviation }\end{array}$ & Rank \\
\hline $\begin{array}{l}\text { High price of poultry feeds force PAPs to have fewer chickens than } \\
\text { what is required for optimal performance }\end{array}$ & 2.3 & 0.86 & 1 \\
\hline $\begin{array}{l}\text { Diseases, in particular Newcastle and Bronchitis, are killing } \\
\text { chickens in large numbers }\end{array}$ & 2.7 & 1.70 & 2 \\
\hline $\begin{array}{l}\text { Water supply is so erratic and unreliable that it is negatively } \\
\text { affecting effective running of poultry business }\end{array}$ & 2.9 & 1.21 & 3 \\
\hline $\begin{array}{l}\text { Veterinary care (drugs and vaccines) for poultry is very expensive } \\
\text { which forces PAP members to resort to using traditional ways that } \\
\text { might not be appropriate for high volume commercial production }\end{array}$ & 4.8 & 1.59 & 4 \\
\hline
\end{tabular}

\section{Key:}

Rank: position per theme

Mean: the lower the mean score, the more pressing is the issue

\section{DISCUSSION}


S. Afr. J. Agric. Ext.

Vol. 44, No. 2, 2016: $147-157$

Dube, Francis

DOI: http://dx.doi.org/10.17159/2413-3221/2016/v44n2a408

\& Maliwichi.

(Copyright)

It was observed that most of the respondents in the current study were women. Ntuli and Oladele (2013) made similar observations through a study carried out in Capricorn District of Limpopo Province. The same authors argued that this could be explained by the fact that most women in rural areas relied on agriculture to earn a living. Emaikwu et al. (2011) lent further support to this view through a study in Nigeria. The latter scholars pointed out that females dominated the poultry enterprise in that country and hoped that it would foster a more careful and accurate application of poultry husbandry practices. A study conducted in Botswana (Badubi, 2011), revealed that in the 59 poultry projects examined 41 projects were women-run, with 17 being entirely men-run and just one project belonging to both men and women.

It was revealed that most members of the PAPs were middle-aged. Youth involvement was almost non-existent. These findings concur with those of Kirui (2014) in Kenya who advocate for youth participation in poultry projects. Even in Botswana, Badubi (2011) found that the 41-50 year old members of PAPs constituted a third of the total number he studied. Ntuli and Oladele (2013) carried out a study in Capricorn District of Limpopo Province of South Africa and observed that youth participation in poultry projects was very poor. A study undertaken in Benin City Metropolis of Nigeria (Ekunwe et al., 2014) revealed that $58 \%$ of the people who were 20-49 years old followed by 33.3\% of those aged 50-59 years were running poultry businesses. All the findings of studies reported above highlight that poultrybased PAPs were popular among middle-aged and elderly women. Thus, extension strategies should be developed taking into account gender and age realities of target groups. Apart from this, there is a need to investigate why younger people were not involved in such income generation activities even though youth unemployment was rife. The results of the studies would help craft more appropriate extension strategies for sustainable mobilisation and active involvement of young people.

Most members of the poultry-based PAPs in Bushbuckridge local Municipality were married. Similar observations were made in past studies in South Africa (Tsitangoni et al., 2010; Ntuli \& Oladele, 2013) and Nigeria (Ekunwe et al., 2014). Ntuli \& Oladele (2013) argue that having a majority of members of PAPs being married is important because it underlines the importance of not outsourcing labour in poultry projects. Members of households in question can carry out all operations.

It was revealed that most beneficiaries of poultry-based PAPs in the current study had attained primary schooling followed by those with secondary school education but had not matriculated. Kirui (2014) carried a study in Kenya in which he concluded that the performance of poultry-based projects was higher if their members had high levels of education. Moreover, in Nigeria Emaikwu et al. (2011) found that education determined the readiness to adopt an innovation that had the potential to increase profitability. High levels of education were also reported to be associated with more sound management and production of poultry projects. Thus, provision of continuous education and training should be an integral pillar of agricultural extension for poultry-based PAPs.

Members of poultry-based PAPs in Bushbuckridge local Municipality relied on middlemen who did not give them discounts when purchasing day-old chicks and feeds. The high costs of feed coupled with long chicken rearing periods due to inadequate markets impacted negatively on income generation capabilities and hampered efforts meant to make the PAPs self-reliant. Middlemen monopolised the feed market and thus high fluctuating prices of inputs characterised the poultry rearing systems. Similar results have been reported from 
S. Afr. J. Agric. Ext.

Vol. 44, No. 2, 2016: $147-157$

Dube, Francis

DOI: http://dx.doi.org/10.17159/2413-3221/2016/v44n2a408

\& Maliwichi.

(Copyright)

studies conducted in Ghana (Ampofo, 2010; Etuah et al., 2013), Botswana (Moreki, 2011) and Limpopo Province of South Africa (Ntuli \& Oladele, 2013). These observations point out the need for the extension service to facilitate the pooling of resources and cooperative purchase of inputs in bulk thereby benefitting from economies of scale. This would weaken the influence of middlemen who thrived on exploiting the fragmentation existing in operational areas. Presumably, inclusion of business intelligence and strategic marketing in extension training programmes might lead to the adoption of this advice.

High mortalities mainly due to poultry diseases were reported to be a major hindrance to the successful running of PAPs. It was explained that this problem existed because of poor and unreliable veterinary support rendered to them. These findings lend support to those of Sil et al. (2002). The latter scholars found that predation and Infectious Bursal Disease (IBD) accounted for considerable losses of poultry. In the current study in Bushbuckridge local Municipality, extension officers singled out poor hygiene as the main challenge that contributed to high mortalities of chickens in the PAPs. They explained that members of the PAPs lacked knowledge of bio-safety and security practices, which in turn clarified why there were no footbaths at entrances to broiler houses. The view that the broiler houses were not hygiene compliant, find support from the Ntuli \& Oladele (2013) study. To underline the importance and need for mandatory training in bio-safety matters in poultry-based PAPs, Anon (2004) observed that supermarkets in Botswana shunned products from small-scale broiler producers. In the same study in Botswana, it was emphasised that supermarkets avoided poultry from the small-scale producers because they were not slaughtered hygienically in accordance with the halal ritual. This highlights the need for the public extension service to package and disseminate this knowledge in easy to read, understand and practice forms. If this is done, it is likely that poultry-based PAPs would have greater chances of success than is the case now.

In an effort to reduce the devastating effects of inadequate veterinary care on growth and development of poultry-based PAPs, members relied on traditional veterinary care such as use of aloe vera (Aloe barbadensis Mill or Aloe perfoliata) and potassium permanganate to infected chickens. Sambo et al. (2015) made similar observations in a participatory evaluation of health and production constraints in Ethiopia. Also, a study carried out in Bangladesh (Billah et al., 2013) revealed that the prevalence of diseases in poultry rearing systems was due to inadequate supply of vaccines and medicines. Thus, it is crucial to strengthen the veterinary extension service such that it is able to intensify training and provision of support to the PAPs. The training should focus on equipping members with knowledge about bio-safety and security practices that can help control diseases as well use of vaccines and animal drugs.

Predators such as snakes, dogs and rodents markedly contributed to the loss of chickens in PAPs run in Bushbuckridge local Municipality. Ntuli \& Oladele (2013) reported that dogs and other predators were a serious impediment to broiler production in Capricorn District of Limpopo Province. Similar reports have been made from studies in Ethiopia (Getu \& Brihan, 2014) and Bindura District of Zimbabwe (Chisango et al., 2015). Poor fencing of operational areas and lack of repellents made it easier for predators to kill poultry. External support to the PAPs with proper fencing of the sites might offset the problem of predation. However, the advisory services should make available knowledge and practical ways of controlling predation. This would help eliminate excessive dependence on external support. In this respect and where possible, extension officers should create opportunities for the members of 
PAPs to learn from each other through workshops and strategic exposure visits that would serve as look and learn tours.

Poor water supply negatively affected the performance of poultry-based PAPs in Bushbuckridge local Municipality. Various studies conducted in South Africa in the past (Masipa, 2010; Tshitangoni et al., 2010; Ntuli \& Oladele, 2013) revealed that shortage of water was one of the major impediments to the successful running of poultry-based PAPs. Badubi (2001) and Moreki (2011) also made similar observations through studies carried out in Botswana. They noted that most small-scale farmers relied on purchasing water from people who had drilled their own boreholes. Thus, it can be concluded that the promotion of the adoption of poultry-based PAPs as an income generation strategy should be coupled with water development efforts. Given the serious water shortage experienced in Bushbuckridge local Municipality, extension support should also include education and training on harvesting, conservation and safe recycling of water.

\section{CONCLUSIONS AND RECOMMENDATIONS}

In this study, it was revealed that various institutional and production challenges constrained the performance of poultry-based PAPs in Bushbuckridge local Municipality. It was evident that provision of cutting edge extension support focusing on development of appropriate infrastructure, purchase of inputs, prevention or control of predation, accessing and utilization of water, disease control and management among others, was needed. The need for the local extension personnel to roll out programmes through which members of poultry-based PAPs can co-learn and be exposed to new ways of running the enterprises was evident. Nevertheless, although the PAPs faced numerous challenges the members continued to operate, which indicated their resilience. Further studies that would unravel the resilience mechanisms that PAPs relied on and their use to prepare new entrants into this industry are required. This would greatly enhance the sustainable contribution of poultry-based PAPs to food and nutrition security plus poverty eradication, in line with the country's drive towards fortifying its developmental state drive.

\section{ACKNOWLEDGEMENTS}

The authors are grateful to the members of PAPs and extension personnel who participated voluntarily in this study. Special gratitude is due to the Ehlanzeni District Department of Agriculture, Rural Development and Land Administration for granting permission to conduct the study. This took place after ethical clearance (Certificate Number: SARDF/14/IRD/02/128) had been secured from the UNIVEN Research Ethics Committee. The UNIVEN Research and Publication Committee funded the study (Project number: SARDF/14/CRD/02).

\section{REFERENCES}

AMPOFO, S. D. 2013. Modelling the Feed Mix for Poultry Production: The Case of ADAMA Musa Farms, Dormaa-Ahenkro in Brong Ahafo Region of Ghana. Unpublished Masters Dissertation. Kwame Nkrumah University of Technology. Kumasi. Ghana.

ANDANI, A. 2012. Is the Developmental State any Longer Appropriate in Overcoming the "Triple Challenge" of Development in South Africa? http://www.ddp.org.za/information (Retrieved 7 June 2015).

ANON 2004. Botswana- Lack of market cripples poultry farming. Botswana Daily News. 
S. Afr. J. Agric. Ext.

Vol. 44, No. 2, 2016: $147-157$

DOI: http://dx.doi.org/10.17159/2413-3221/2016/v44n2a408

Dube, Francis

\& Maliwichi.

Retrieved 03/11/2010 from http://en.engormix.com/MA-poultry-industry/news/botswanalack-market-cripples-t3991/p0.htm.

AYEE, J. R. E. 2013. The Developmental State Experiment in Africa: The Experiences of Ghana and South Africa. The Round Table, 102 (3):259-280. http://dx.do:org/10.1080/00 358 533.2013.794 577. (Retrieved 1 May 2015).

BADUBI, S. S. 2001. Small-Scale Poultry Production Systems in Botswana and Evaluation of a Natural Zeolite in Broiler Diets. Unpublished Masters Dissertation. Massey University. Palmerston North. New Zealand.

BILLAH, S. M., NARGIS, F., HOSSAIN, M. E., HOWLIDER, M. A. R. \& LEE, S. H 2013. Family Poultry Production and Consumption Patterns in Selected Households of Bangladesh. Journal of Agricultural Extension and Rural Development, 5 (4): 62-69

CHISANGO, F. F. T., TEMBACHAKO, D. \& MUPOPERI, O. 2015. An Analysis of Factors Hindering the Development of Indigenous Chicken Production in Smallholder Farming Countries of Zimbabwe: A Case of Ward 10 in Bindura District. International Journal of Management and Economics Invention, 1 (5): 230-243.

EKUNWE, P. A., FIONA, O. \& OGBEIDE, R. 2014. Socio-Economic Factors Influencing Broilers Marketing in Benin City Metropolis, Edo State, Nigeria. Journal of Agricultural Science, 13 (4) $78-81$.

EMAIKWU, K. K., CHIKWENDU, D. O. \& SANI, A. S. 2011. Determinants of flock size in broiler production in Kaduna State of Nigeria. Journal of Agricultural Extension and Rural Development, 3(11): 202-211

ETUAH, S., NURAH, G. K. \& YANKYERA, A. O. 2013. Profitability and Constraints of Broiler Production: Empirical Evidence from Ashanti Region of Ghana. Journal of Business Economics, 5 (2): 228-243.

GALLAGHER, K. D. 2002. Self-Financed Field Schools: Helping Farmers go Back to School in IPM/IPM.FAO/UN. Rome, Italy.

GETU, A. \& BIRHAN, M. 2014. Chicken Production Systems, Performance and Associated Constraints in North Gondar Zone, Ethiopia. Journal of Fisheries and Livestock Production, 2:115 DOI: 10. 4172/2332-2608.

KIRUI, K. 2014. Factors Influencing Performance of Poultry Farming Projects In Bureti Sub County Kericho, Kenya. Unpublished Masters Dissertation, University of Nairobi Kenya.

MAKHALANE, V. 2009. The Assessment of Factors Contributing to the Sustainability of Poverty Relief Projects in the Eastern Cape. Unpublished Masters' Thesis. Nelson Mandela Metropolitan University.

MASIPA, M. P. 2010. An Assessment of the Sustainability of Poverty Eradication Projects in Rural Communities of Capricorn District Municipality: Limpopo Province in South Africa. Unpublished Ph.D. Thesis. University of Venda.

MBEKI, T. 2006. State of the Nation Address of the President of South Africa, $3^{\text {rd }}$ February 2006, Cape Town.

MERRIAM, S. B. 1998. Qualitative Research and Case Study Applications in Education: Revised and Expanded Case Study Research in Education. San Francisco: Jossey-Basey.

MKANDAWIRE, T. 2012. Building the African State in the Age of Globalisation: The Role of Social Compacts and Lessons for South Africa, Inaugural Lecture, Mapungubwe Institute for Strategic Reflection, South Africa, April 17-19, 2012.

MOREKI, J. C. 2011. Challenges in small-scale broiler production in Botswana. Journal of Agricultural Technology. 7(6): 1579-1587.

NTULI, V. \& Oladele, O. I. 2013. Analysis of Constraints Faced by Small-scale Broiler Farmers in Capricorn District in Limpopo Province. Life Science Journal, 10 (1): 29902996. 
ROUTLEY, L. 2014. Developmental States in Africa? A Review of Ongoing Debates and Buzzwords. Development Policy Review, 32 (2):157-59.

SAMBO, E., BETTRIDGE, J., DESSIE, T., AMARE, A., HABTE, T., WIGLEY, P. \& CHRISTLEY, R. M. 2015. Participatory evaluation of chicken health and production constraints in Ethiopia. Preventive Veterinary Medicine, 118 (1): 117-127. http://doi.org/10.1016/j.prevetmed.2014.10.014

SIL, G. C., DAS. P. M., ISLAM, M. R. \& RAHMAN, M. M. 2002. Management and Disease Problems of Cockerels in some Farms of Mymensingh, Bangladesh. International Journal of Poultry Science, 1 (4): 102-105.

STATISTICS SOUTH AFRICA 2011. Statistics South Africa, By Place, Bushbuckridge Local Municipality, Pretoria, South Africa.

TSHITANGONI, M., OKORIE, A. \& FRANCIS, J. 2010. Performance of Poverty Alleviation Projects in South Africa: The Case of the Vhembe District, Limpopo Province. Science Research Essays, 6 (5):1005-1012.

URBAN-ECO DEVELOPMENT ECONOMISTS. 2013. Assessment of Cooperatives in the Poultry Industry: Final Report, Addressing the Needs, Opportunities and Challenges of Cooperatives and Collectively-owned Enterprises in the Poultry Industry and Related Industries, Hatfield, Pretoria, South Africa. 